\title{
A robust and reproducible animal serum-free culture method for clinical-grade bone marrow-derived mesenchymal stromal cells
}

\author{
Anita Laitinen • Sofia Oja • Lotta Kilpinen • Tanja Kaartinen • \\ Johanna Möller • Saara Laitinen • Matti Korhonen • \\ Johanna Nystedt
}

Received: 28 May 2014/Accepted: 30 December 2014/Published online: 17 March 2015

(C) The Author(s) 2015. This article is published with open access at Springerlink.com

\begin{abstract}
Efficient xenofree expansion methods to replace fetal bovine serum (FBS)-based culture methods are strongly encouraged by the regulators and are needed to facilitate the adoption of mesenchymal stromal cell (MSC)-based therapies. In the current study we established a clinically-compliant and reproducible animal serum-free culture protocol for bone marrow-(BM-) MSCs based on an optimized platelet-derived supplement. Our study compared two different platelet-derived supplements, platelet lysate PL1 versus PL2, produced by two different methods and lysed with different amounts of freeze-thaw cycles. Our study also explored the effect of a low oxygen concentration on BM-MSCs. FBS-supplemented BM-MSC culture served as control. Growth kinetics, differentiation and immunomodulatory potential, morphology, karyotype and immunophenotype was analysed. Growth kinetics in long-term culture was also studied. Based on the initial results, we chose to further process develop the PL1-supplemented culture protocol at $20 \%$ oxygen. The results from 11 individual BM-MSC batches expanded in the
\end{abstract}

Matti Korhonen and Johanna Nystedt have shared last authorship.

A. Laitinen $(\bowtie) \cdot$ S. Oja $\cdot$ L. Kilpinen .

T. Kaartinen · J. Möller · S. Laitinen .

M. Korhonen · J. Nystedt

Research and Cell Therapy Services, Finnish Red Cross

Blood Service, Kivihaantie 7, 00310 Helsinki, Finland

e-mail: anita.laitinen@bloodservice.fi chosen condition were consistent, yielding $6.60 \times 10^{9} \pm$ $4.74 \times 10^{9}$ cells from only $20 \mathrm{ml}$ of bone marrow. The cells suppressed T-cell proliferation, displayed normal karyotype and typical MSC differentiation potential and phenotype. The BM-MSCs were, however, consistently HLA-DR positive when cultured in platelet lysate (7.5-66.1\%). We additionally show that culture media antibiotics and sterile filtration of the platelet lysate can be successfully omitted. We present a robust and reproducible clinically-compliant culture method for BM-MSCs based on platelet lysate, which enables high quantities of HLA-DR positive MSCs at a low passage number (p2) and suitable for clinical use.

Keywords Mesenchymal stromal cell (MSC) - Low oxygen · Platelet lysate (PL) · FBS · HLA-DR

$\begin{array}{ll}\text { Abbreviations } \\ \text { FBS } & \text { Fetal bovine serum } \\ \text { MSC } & \text { Mesenchymal stromal/stem cell } \\ \text { BM } & \text { Bone marrow } \\ \text { PL } & \text { Platelet lysate } \\ \text { PRP } & \text { Platelet rich plasma } \\ \mathrm{CO}_{2} & \text { Carbon dioxide } \\ \text { FRCBS } & \text { Finnish Red Cross Blood Service } \\ \text { MNC } & \text { Mononuclear cell } \\ \text { CFU-F } & \text { Colony forming unit-fibroblasts } \\ \text { PD } & \text { Population doubling } \\ \text { CD } & \text { Cluster of differentiation } \\ \text { HLA } & \text { Human leucocyte antigen }\end{array}$




$\begin{array}{ll}\text { Neu5Gc } & N \text {-Glycolylneuraminic acid } \\ \text { PB } & \text { Peripheral blood } \\ \text { SD } & \text { Standard deviation } \\ \text { ANOVA } & \text { Analysis of variance } \\ \text { GMP } & \text { Good manufacturing practice } \\ \text { ISCT } & \text { International Society of Cell Therapy } \\ \text { MLR } & \text { Mixed lymphocyte reaction }\end{array}$

\section{Introduction}

Mesenchymal stromal cells (MSCs) are multipotent non-hematopoietic cells that are commonly isolated from bone marrow (BM) or adipose tissue. In the BM, these cells comprise only a small population of cells, 0.001-0.01\% (Pittenger et al. 1999), however they can be isolated and expanded for several passages in vitro. MSCs are able to differentiate to cell types of mesodermal origin such as adipocytes, chondrocytes and osteoblasts (Pittenger et al. 1999), and have thus generated interest in their potential application in tissue regenerative therapies (Dimarino et al. 2013; Sensebe and Bourin 2009). MSCs also potently suppress $\mathrm{T}$-cell mediated rejection reactions and ameliorate clinical graft-versus-host reactions (Aggarwal and Pittenger 2005; Le Blanc et al. 2008). Furthermore, via activity on innate immune cells such as dendritic cells (DCs) and myeloid-derived suppressor cells (MDSCs) and regulatory T-cell (Aggarwal and Pittenger 2005; Yen et al. 2013), MSCs may have potential in inducing transplantation tolerance (Kim et al. 2013; Sensebe and Bourin 2009; Shi et al. 2011).

Several trials have explored the clinical utility of MSCs, both for immunosuppressive and regenerative purposes. These therapies require considerable amounts of cells. Traditionally the cells are expanded in vitro in monolayer cultures containing fetal bovine serum (FBS). The use of animal-derived components is associated with a risk of transmission of xenogenic infectious agents and immunization (Cervenakova et al. 2011; Horwitz et al. 2002; Liu et al. 2008; Sundin et al. 2007) and the use of alternative supplements or completely defined culture media would thus be preferred and is highly encouraged by the regulators (Guideline on human cell-based medicinal products, EMEA/CHMP/410869/2006 and note for guidance on minimising the risk of transmitting animal spongiform encephalopathy agents via human and veterinary medicinal products, 0EMA/410/01 rev.3). A number of studies have examined supplementing MSC cell culture media with different human blood-derived components such as platelet-derived supplements, human serum or umbilical cord blood serum (Bieback et al. 2009; Doucet et al. 2005; Fekete et al. 2012a; Schallmoser et al. 2007; Shafaei et al. 2011; Shahdadfar et al. 2005; Shetty et al. 2007). The methods employed for the production of platelet extracts are diverse (Bieback 2013). They are produced either from platelet rich plasma (PRP), which is commonly prepared by combining four buffy coat units and one AB-plasma unit with subsequent leukocyte-depletion (Schallmoser et al. 2007), or from platelet concentrates in additive solution, even expired ones (Bieback et al. 2009; Fekete et al. 2012a). Mojica-Henshaw et al. (2013) have shown that serum-converted platelet lysate (PL) can also be used as medium supplement, with the advantage that porcine-derived heparin can be omitted from the culture medium. The release of growth factors from platelets is usually induced by $2-4$ freeze-thaw cycles of the platelet units or by activating the platelets with thrombin (Bieback et al. 2009). It has been suggested that at least four repeated freezethaw cycles might further enhance the liberation of growth factors from the platelets (Wasterlain et al. 2012). The final PL supplements are produced by either pooling several units (Schallmoser et al. 2007) or using just one unit (Horn et al. 2010).

Besides the culture medium the environment of the cells in vitro is defined by the surrounding atmosphere. Traditionally cell cultures are performed at normal atmospheric oxygen concentration $(20 \%)$ in incubators where only the carbon dioxide $\left(\mathrm{CO}_{2}\right)$ level is regulated. The physiological oxygen concentration in human tissues is, however, much lower (2-13\%) and several stem cell types proliferate more rapidly, undergo significantly less apoptosis and DNA damage at low oxygen concentrations (Csete 2005; Estrada et al. 2012; Mohyeldin et al. 2010; Sullivan et al. 2006). Interestingly, it has been shown that low oxygen might be beneficial for the growth of MSCs at least in later passages (Dos Santos et al. 2010; Drela et al. 2014; Ren et al. 2006). In our study we wanted to test if low oxygen significantly improves cell growth also at low cell passages.

The expansion of MSCs in vitro is a necessary step to gain a sufficient number of cells for clinical needs. 
The culture time must, however, be kept to a minimum in order to avoid detrimental effects on the cells. Commonly used MSC cell doses that are used in the clinic for immunomodulatory purposes are in the range of $1-2 \times 10^{6} / \mathrm{kg}$ (Ball et al. 2013; Prasad et al. 2011; Ringden et al. 2006). As even six doses may be needed per patient, it equals over $10^{9}$ cells for a single adult patient. It would clinically also be preferable to produce these doses from a single MSC donor. The purpose of this study was therefore to develop a reproducible culture method for clinical MSCs based on platelet-derived supplements that would yield sufficient cell numbers for at least six treatments from only $20 \mathrm{ml}$ of BM.

Since many research papers have described a successful replacement of FBS by PL in MSC culture, we wanted to explore if a PL-based protocol to culture BM-MSCs could be further developed to a manufacturing method that (1) would yield high numbers $\left(>10^{9}\right.$ cells) of high quality cells after a low amount of passaging and from only $20 \mathrm{ml}$ of BM and (2) could be easily and cost-effectively adapted to clinical- and GMP-grade cell manufacturing. In our current study we compared two different PL supplements, PL1 and PL2, to determine which would be better suited in a clinical cell manufacturing protocol. Our study also explored several other parameters to establish the most optimal and robust culture protocol for low passage BM-MSCs: the effect of a low oxygen concentration (3 vs $20 \%$ concentration), the effect of repeated freezethaw cycles (five vs two) on the functionality of the PL and the omission of antibiotics and the sterile filtration step of the PL supplemented culture media. FBSsupplemented BM-MSC culture served as control.

We present a clinically-compliant, antibiotic-free BM-MSC culture protocol based on unfiltered PL supplement that can replace FBS also in large scale cell expansion and yielding high quantities of HLADR positive MSCs for clinical use.

\section{Materials and methods}

Platelet lysate supplements

Two different PL supplements (PL1 and PL2) were used in the study, see Table 1 for an overview of the PL supplement characteristics. All platelet units used in the study were produced by a licensed blood

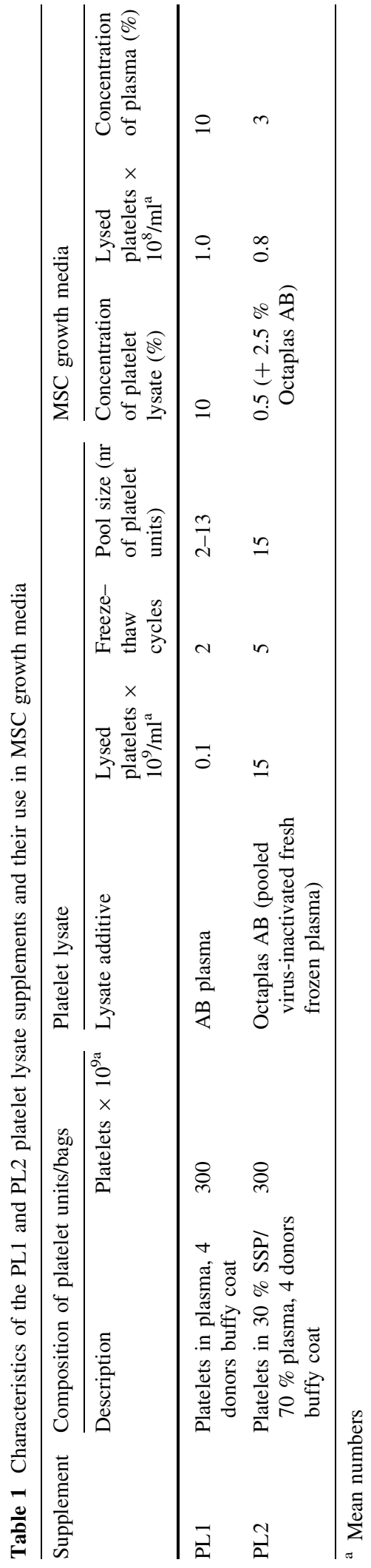


Table 2 Functionality testing of the platelet lysate 1 (PL1) supplement pools based on MSC population doubling (PD) in a 5-7 day proliferation test. MSCs from 2 to 4 different donors served as responder cells

\begin{tabular}{lcccc}
\hline PL1 pool & Number of PRP units & Number of donors & Number of PDs (mean) & Range of PDs \\
\hline Pool 1 & 2 & 8 & 4.44 & $3.0-5.88$ \\
Pool 2 & 3 & 12 & 4.54 & $3.17-5.91$ \\
Pool 3 & 6 & 24 & 4.82 & $3.46-6.19$ \\
Pool 4 & 4 & 16 & 5.27 & $4.75-5.78$ \\
Pool 5 & 4 & 16 & 5.00 & $4.32-5.83$ \\
Pool 6 & 11 & 44 & 5.11 & $4.39-5.81$ \\
Pool 7 & 13 & 52 & 3.82 & $3.32-4.32$ \\
\hline
\end{tabular}

establishment, the Finnish Red Cross Blood Service (FRCBS) in Helsinki, Finland. The blood donors were tested according to the Finnish regulations for the preparation of blood components and in line with the regulations by the Council of Europe [Guide to the preparation, use and quality assurance of blood components, Recommendation No.R (95)15]. The blood donors tested negative for Anti-HCV, AntiHIV-1+2, HBsAg, Syphilis, HCV-RNA, HIV-1RNA, HBV-DNA and HAV-RNA and Parvo B19DNA levels were below $10^{5} \mathrm{IU} / \mathrm{ml}$. The platelet units used in this study were done following standard operating procedures within the quality system of the FRCBS and with clear release criteria involving the donor test results, platelet amounts, residual leukocytes and weight.

PL1 was essentially produced as described by Schallmoser et al. (2007). PRP units were produced by combining buffy coats of four individual blood donors with one unit of AB-plasma. The platelets were separated by centrifugation and the remaining leukocytes were removed by filtration, after which the units were frozen at $-20{ }^{\circ} \mathrm{C}$. PL1 pools were subsequently produced by pooling 2-13 thawed PRP units and the combined pool was then frozen in aliquots at $-20{ }^{\circ} \mathrm{C}$. Thus each PL1 pool originated from buffy coats of 8-52 individual blood donors and was frozen twice during production. The efficiency of each PL1 pool to support MSC growth was tested in a 5-7 day proliferation assay and with 2-4 different BM-MSC batches as responder cells (Table 2). The pools were released for use if the responder cells exhibited a population doubling of 3 and above during the 5-7 day assay. To produce PL2, expired bags of platelet concentrates in $30 \%$ additive solution SSP (MacoPharma, Langen, Germany and $70 \%$ plasma) were centrifuged at $3,200 \times g$ for $20 \mathrm{~min}$ at room temperature. The pellets were suspended in
$20 \mathrm{ml}$ of pooled frozen AB-plasma (Octaplas AB, Octapharma AG, Lachen, Switzerland) per bag of platelets, frozen at $-70{ }^{\circ} \mathrm{C}$ and subsequently thawed in a $+37{ }^{\circ} \mathrm{C}$ water bath. After five freeze-thaw cycles the platelets were centrifuged at $3,200 \times g$ for $20 \mathrm{~min}$ at room temperature and the supernatants were collected and stored at $-20{ }^{\circ} \mathrm{C}$. Each PL2 lysate was tested for efficiency by supporting MSC growth at least at the same levels as FBS before producing the PL2 pool. The PL2 pool for this study was prepared by pooling 15 individual PL2 units thus originating from 60 individual donors.

All pools of PL were also tested for sterility by BacT/ ALERT (bioMérieux, SA, Marcy-I'Etoile, France). When thawed for use the supplements were finally centrifuged at $3,200 \times g$ for $20 \mathrm{~min}$ at room temperature (RT) immediately before use and the supernatant was used.

Bone marrow harvest

BM was collected from 15 voluntary healthy donors, aged 20-40, after written informed consent. The study was approved by the Ethical Committee of the Hospital District of Helsinki and Uusimaa. $20 \mathrm{ml}$ of $\mathrm{BM}$ was drawn under local anaesthesia from the posterior iliac crest into heparinized syringes. The samples were processed within $2 \mathrm{~h}$ from harvest. For mononuclear cell (MNC) isolation the BM samples were diluted 1:3 with DPBS CTS ${ }^{\mathrm{TM}}$ (Life Technologies, Thermo Fisher Scientific, Waltham, MA, USA) and 2 mM EDTA ( $\mathrm{pH} 7.2$ ) or later on in the study with Versene (EDTA) $0.02 \%$ (Lonza, Basel, Switzerland) and layered on Ficoll-Paque PREMIUM (GE Healthcare Bio-Sciences, Uppsala, Sweden) and centrifuged at $400 \times g, 40 \mathrm{~min}$ at RT. The BM-MNCs were collected, washed with DPBS CTS ${ }^{\text {TM }}$-EDTA/Versene and counted as described in the next chapter. 
Culture of MSCs

The BM-MSC basal medium consisted of D-MEM (low glucose, Life Technologies), $100 \mathrm{U} / \mathrm{ml}$ penicillin, $100 \mu \mathrm{g} / \mathrm{ml}$ streptomycin (Life Technologies) and $40 \mathrm{IU} / \mathrm{ml}$ heparin (Heparin LEO $^{\circledR} 5000 \mathrm{IE} / \mathrm{KY} / \mathrm{ml}$, Leo Pharma, Malmö, Sweden) to prevent gelatinization and avoid clots. Later on in the study, the antibiotics were omitted when process developmental work was transferred to a cleanroom environment. The basal medium was supplemented either with $10 \%$ PL1 or with $0.5 \%$ PL2 and $2.5 \%$ AB-plasma (Octaplas, Octapharma), see Table 1. The control medium consisted of basal medium and $10 \%$ FBS without heparin. The PL1 and PL 2 containing media were initially sterile filtrated with a $0.22 \mu \mathrm{m}$ filter before use in culture. Later on in the study and opposite to other published protocols (Schallmoser et al. 2007), we omitted the filtration process with the PL1 supplemented medium as clinically-compliant and xenofree filters were not available in the culture scale needed. The BM-MNCs were plated in culture vessels at $400,000 \mathrm{cells} / \mathrm{cm}^{2}$ and were placed in a humidified incubator at $+37{ }^{\circ} \mathrm{C}, 5 \%$ $\mathrm{CO}_{2}$ with either 3 or $20 \%$ oxygen. After 3 days the wells were washed four times with DPBS CTS ${ }^{\mathrm{TM}}$ to remove non-adherent cells and the medium was changed. The medium was changed twice weekly until the cells reached $90 \%$ confluency. At each passage the vessels were washed with DPBS CTS ${ }^{\mathrm{TM}}$ and the cells were detached with TrypLE ${ }^{\mathrm{TM}}$ Express (Life Technologies) and later on in the study with TrypLE ${ }^{\mathrm{TM}}$ Select CTS $^{\text {TM }}$ (Life Technologies) and reseeded at 1,000 cells $/ \mathrm{cm}^{2}$. The cell number and viability of the cells was determined using a Bürker-chamber or NucleoCounter NC-100 ${ }^{\mathrm{TM}}$ (ChemoMetec, Allerod, Denmark). Aliquots of cells in interim phases of culture (p0, p1) were frozen in liquid nitrogen and thawed and cultured for analysis if needed. Freezing of the cells was done in the initial phase of the study in $50 \%$ of the appropriate proliferation medium, $40 \% \mathrm{FBS}$ and $10 \%$ DMSO Hybri-Max ${ }^{\mathrm{TM}}$ (Sigma-Aldrich, Ayrshire UK), but later on in the study in $90 \%$ human albumin (Albunorm 200 g/l, Octapharma) and $10 \%$ Cryoserv $^{\circledR}$ DMSO (Bioniche Pharma, Lake Forest, IL, USA). All proliferation kinetic and long-term culture studies were done with cells without interim freezing.

The PL1-supplemented culture protocol at $20 \%$ oxygen concentration was chosen for further process development work and was developed towards a clinically and GMP-compliant method. Large-scale MSC culture was developed using 1-, 2- and 5-STACK culture vessels (CellStacks ${ }^{\circledR}$, Corning Inc., Corning, NY, USA). During the large-scale process development phase, all the materials were clinically- and GMP-compliant. In the final process development stage of the study, also the filtering of the medium and the antibiotics were omitted from the culture medium as the cell production was performed in class A cleanroom environment.

\section{Proliferation kinetics}

To determine the colony forming unit-fibroblasts (CFU-F) content of the starting BM-MNC material, the BM-MNCs were plated in six-well plates (Corning Inc.) at 400,000 cells $/ \mathrm{cm}^{2}$ and cultured for 5-10 days at $+37{ }^{\circ} \mathrm{C}, 5 \% \mathrm{CO}_{2}, 20 \%$ oxygen. The cells were then fixed with methanol and stained with Giemsa solution (Merck KGaA, Darmstadt, Germany).

The number of population doublings (PD) was calculated using the formula $\mathrm{N}_{\mathrm{H}}=2^{\mathrm{PD}} \times \mathrm{N}_{1}$ in which $\mathrm{N}_{\mathrm{H}}$ is the number of harvested cells $/ \mathrm{cm}^{2}$ and $\mathrm{N}_{1}$ is the number of seeded cells $/ \mathrm{cm}^{2}$. PD is then determined as $\mathrm{PD}=\log _{2}\left(\mathrm{~N}_{\mathrm{H}} / \mathrm{N}_{1}\right)$. At passage zero the CFU-F number in the original $\mathrm{BM}$ aspirate was the initial $\mathrm{N}_{1}$. The PD time was calculated as length of passage (days)/number of PDs reached during passage.

\section{Genetic stability}

Cells at passage two were plated in cell culture flasks (Corning) at 1,000 cells $/ \mathrm{cm}^{2}$ and grown to $70-80 \%$ confluency for karyotyping. At least 20 mitotic cells were analysed from each sample by conventional G-band analysis by an accredited laboratory (Medix Laboratories, Espoo, Finland). Results were informed as either normal karyotype (46, XX or 46, XY) or abnormal (with corresponding chromosomal abnormality).

\section{Differentiation assays}

To assess the adipogenic and osteogenic potential of the BM-MSCs, cells from passage two were seeded onto 12-well plates (Nunc) at 3,000 cells $/ \mathrm{cm}^{2}$ and the cells were grown to confluency. For adipogenic differentiation the cells were changed into an adipogenic induction medium for 2-3 days after which the cells were incubated in terminal adipogenic medium for 
1-2 weeks. The induction medium and terminal differentiation medium consisted of the same adipogenic basal medium containing alpha-MEM Glutamax, $10 \%$ FBS, $20 \mathrm{mM}$ HEPES, $100 \mathrm{U} / \mathrm{ml}$ penicillin, $100 \mu \mathrm{g} / \mathrm{ml}$ streptomycin (all from Life Technologies), $0.5 \mu \mathrm{g} / \mathrm{ml}$ insulin (Promocell, Heidelberg, Germany) and $0.1 \mathrm{mM}$ indomethacin (Sigma-Aldrich, St Louis, MO, USA). In addition the induction medium contained $0.2 \mathrm{mM}$ 3-isobutyl-1-methylxanthine (IBMX), and $0.4 \mu \mathrm{g} / \mathrm{ml}$ dexamethasone (both from PromoCell) and the terminal differentiation medium contained $3 \mu \mathrm{g} / \mathrm{ml}$ Ciglitazone (PromoCell) (Suila et al. 2011). After differentiation the cells were fixed with $4 \%$ paraformaldehyde (PFA) for Sudan III (Sigma-Aldrich) staining.

For osteogenic differentiation the cells were cultured in osteogenic medium for 3-4 weeks. The osteogenic medium consisted of $\alpha$-MEM supplemented with $10 \%$ FBS, 20 mM HEPES, 2 mM L-glutamine (all from Life Technologies), $0.1 \mu \mathrm{M}$ dexamethasone, $10 \mathrm{mM} \beta$ glycerophosphate, $0.05 \mathrm{mM}$ L-ascorbic acid-2-phosphate (all from Sigma-Aldrich) and penicillin-streptomycin (Life Technologies). Animal serum-free osteogenic differentiation medium consisted of D-MEM Glutamax (low glucose, Life Technologies), $10 \% \mathrm{PL} 1$ and $40 \mathrm{IU} / \mathrm{ml}$ heparin (LeoPharma), $0.1 \mu \mathrm{M}$ dexamethasone, $10 \mathrm{mM} \beta$-glycerophosphate, $0.05 \mathrm{mM}$ L-ascorbic acid-2-phosphate. After differentiation the cells were fixed with $4 \%$ PFA for von Kossa staining.

For chondrogenic differentiation 200,000 cells from passage two were pelleted into a micromass by centrifugation at $400 \times g$ for $5 \mathrm{~min}$ in $15 \mathrm{ml}$ conical polypropylene tubes. The pellets were cultured for 2 weeks in chondrogenic medium that consisted of D-MEM (high glucose, containing $0.1 \mathrm{mM}$ pyruvate, Life Technologies), supplemented with $10 \mathrm{ng} / \mathrm{ml}$ transforming growth factor beta (TGF- $\beta$ ), $0.1 \mu \mathrm{M}$ dexamethasone, $0.1 \mathrm{mM}$ L-ascorbic acid-2-phosphate, $40 \mu \mathrm{g} / \mathrm{ml} \mathrm{L}$-proline (all four from Sigma-Aldrich), $1 \times$ ITS + premix (BD Biosciences, Bedford, MA, USA) and penicillin-streptomycin (Life Technologies). The cell pellets were fixed with $10 \%$ formalin, embedded in paraffin, cut into sections and stained with Alcian blue (Sigma-Aldrich) and Nuclear fast red (Merck).

Flow cytometry analysis

For analysis of immunophenotype the cells were detached with TrypLE ${ }^{\mathrm{TM}}$-express (Life Technologies) and washed with FACS buffer solution (0.3\% BSA (Sigma-Aldrich) in PBS-2 mM EDTA). Fluorescein isothiocyanate (FITC), phycoerythrin (PE) or allophycocyanin (APC)-conjugated antibodies against CD13, CD14, CD19, CD29, CD44, CD45, CD49e, CD73, HLA-DR, HLA-ABC (all from BD Pharmingen, San Diego, CA, USA), CD34 (Miltenyi Biotec GmbH, Gladbach, Germany), CD90 (StemCell Technologies Inc., Vancouver, BC, Canada) and CD105 (Abcam, Cambridge, UK) were used for direct labelling of the cells. Appropriate FITC-, PE- and APC-conjugated isotype controls (all from BD Biosciences) were used. $N$-Glycolylneuraminic acid (Neu5Gc, Gc-Free, Biolegend, San Diego, CA, USA) staining was performed according to manufacturer's instructions followed by AlexaFluor 488 labelled goat anti-chicken secondary antibodies (Molecular Probes, Invitrogen, Eugene, OR, USA). $1 \mu \mathrm{M}$ Sytox Blue (Molecular Probes) was used to exclude dead cells. The cells were analysed with FACSAria flow cytometer and FACSDiva 5.0.3 (BD, San Jose, CA, USA) and FlowJo 7.6.1 softwares (TreeStar, Ashland, OR, USA).

Immunosuppression assay

To interrogate the capacity of MSCs to suppress T-cell proliferation the cells were co-cultured with peripheral blood mononuclear cells (PB-MNC). $1.5 \times 10^{5}$, $0.75 \times 10^{5}$ or $0.3 \times 10^{5} \mathrm{MSC}$ were suspended in RPMI 1640 medium supplemented with $5 \%$ FBS and penicillin-streptomycin (all from Life Technologies) and plated in 48-well plates. The MSCs were allowed to adhere onto the plates in an incubator before the PBMNCs were added.

PB-MNCs were isolated from buffy coats by FicollPaque Plus (GE Healthcare, Helsinki, Finland) gradient centrifugation and labelled with $2.5 \mu \mathrm{M}$ CFSE [5(6)-carboxyfluorescein diacetate $\mathrm{N}$-succinimidyl ester, Molecular Probes] in $0.1 \%$ HSA-PBS (human serum albumin, Sanquin, Espoo, Finland) for $5 \mathrm{~min}$ at room temperature. $1.5 \times 10^{6}$ labelled PB-MNCs were then added to the co-culture. For T-cell activation $0.1 \mu \mathrm{g} / \mathrm{ml}$ of CD3 antibody (clone Hit3a, BioLegend, San Diego, CA, USA) was added to the wells. T-cell proliferation was recorded after 4 days of co-culture as dilution of fluorescent dye by flow cytometry. The division index (Flow Jo software v.7.6.1) was used to represent the extent of cell division. 
Statistical analysis

All data are presented as the mean \pm standard deviation (SD) unless mentioned otherwise. The differences in mean values were tested by one-way analysis of variance (ANOVA) and the Tukey's post hoc test. The data were analyzed with GraphPad Prism software version 5.04 (GraphPad Software, La Jolla, CA, USA) and statistical programming software R (version 2.14.0). The differences were considered significant when $p<0.05$.

\section{Results}

BM processing

The BM samples were initially aspirated into heparinized syringes, but since some of the BM samples contained clots the standard operating procedures were modified to also include 2,500 IU of heparin per $10 \mathrm{ml}$ syringe. The MNC yield after gradient centrifugation was $2.98 \times 10^{6} \pm 1.310^{6} / \mathrm{ml}$ of BM.

Small pools of PL1 are as efficient as larger pools

Each pool of PL1 was tested using 2-4 individual MSC batches as responder cells. Tested pools consistently supported the expansion of MSCs through 3.0-6.2 PDs in a 5-7 day proliferation assay (Table 2). Pools produced from two PRP units were as efficient as ones from 13 units. For practical reasons, large pools (e.g. pools of 8-10 PRP units) are preferable.

\section{PL1 provides a good support for MSC growth}

We compared the ability of three different culture medium supplements, PL1, PL2 and FBS, to support MSC growth up to passage two in 20 and $3 \%$ oxygen. There was no statistical difference in total cell yield or cumulative PD between different culture conditions ( $p=0.42$ and 0.99 , respectively, Fig. 1a, b). However, cells cultured in PL1-medium reached the highest cell yields (extrapolated cell numbers from $20 \mathrm{ml}$ of BM were $6.31 \times 10^{9} \pm 9.82 \times 10^{9}$ in $20 \%$ oxygen and $4.81 \times 10^{9} \pm 6.78 \times 10^{9}$ in $3 \%$ oxygen) and the highest PDs $(22.4 \pm 2.9$ PDs in $20 \%$ oxygen and $23.0 \pm 2.5$ PDs in $3 \%$ oxygen) within the shortest PD
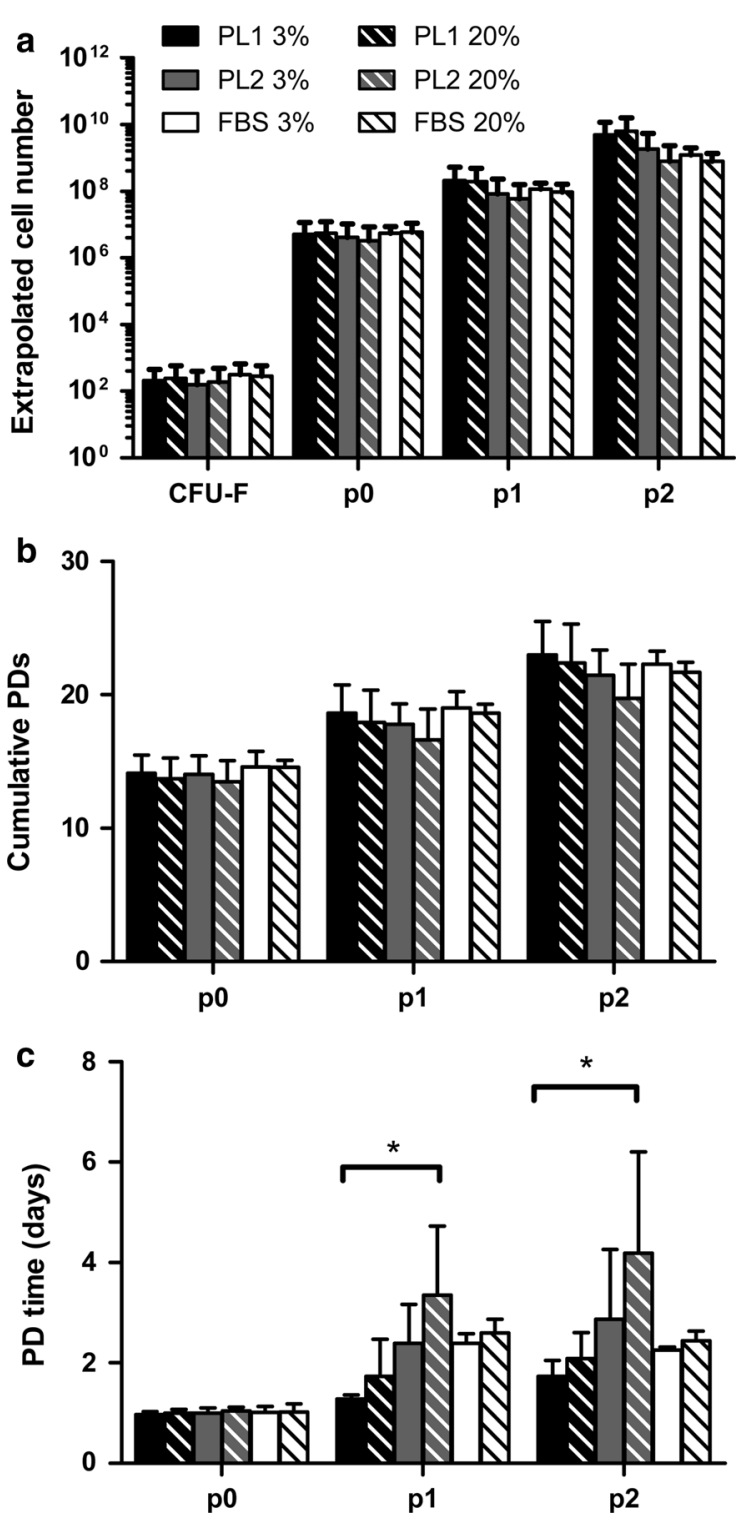

Fig. 1 Proliferation kinetics of cells cultured in six different culture conditions. a Extrapolated cell yield from $20 \mathrm{ml}$ of BM up to passage two. $\mathbf{b}$ Cumulative PDs and $\mathbf{c}$ PD time at different passages from BM-MNC to passage 2. b, c The CFU-F numbers were used as the starting number of the cells at passage 0 . Data are represented as mean $\pm \operatorname{SD}(n=4)$, except for FBS cultures where only mean values are shown $(n=2)$

times $(2.1 \pm 0.5$ days in $20 \%$ oxygen and $1.7 \pm$ 0.3 days in $3 \%$ oxygen at passage 2 ), see Fig. 1 . When PL1 cultured cells were compared with PL2 the PD time was significantly shorter regardless of oxygen conditions ( $p=0.015$ by one-way ANOVA, Fig. $1 c)$. There was no statistical difference in the PD time 
between PL1 and FBS cultured cells. The use of $3 \%$ oxygen led to a trend of shorter PD times with each medium reaching statistical significance only between cells cultured in PL1-medium in $3 \%$ oxygen versus PL2-medium in $20 \%$ oxygen ( $p=0.04$, Fig. $1 c)$.

After these initial experiments, we chose to test the suitability of the PL1-medium and $20 \%$ oxygen for large-scale expansion using suitable large cell culture vessels of MSCs with 11 subsequent bone marrow samples. The mean CFU-F number/ml of BM was $17.30 \pm 10.83$, representing $0.0001-0.0009 \%$ of BM-MNCs. We set $10^{9}$ cells at passage 2 as the goal for the cell culture process, thus sufficient for 6 cell doses for a patient of $80 \mathrm{~kg}$. As can be seen in Fig. 2, the goal of $10^{9}$ cells was reached at passage two in $73 \%$ of the BM-MSC batches (8/11) and within 21-26 PDs (mean cell number $6.6 \times 10^{9} \pm 4.74 \times 10^{9}$ ). Clotted BM aspirates performed poorly and was identified as the primary reason behind a lower cell yield as passage 2. Passage two was reached within 21-35 days (Fig. 2). All tested large cell culture vessels performed equally well and with consistent cell yield $/ \mathrm{cm}^{2}(p=0.79)$ indicating a robust and even cell expansion in the chosen large cell culture vessels and independent of the number of layers in the vessel (Fig. 3). The karyotype of passage two cells was normal (46, XX or 46, XY) in all 11 BM-MSC batches.

Long-term cultures revealed that the proliferation of cells cultured in PL1-medium was arrested after 46 PDs and was superior to the cells cultured in PL2- medium and FBS-medium, which ended proliferation after 27 PDs and 38 PDs, respectively (Fig. 4). Total culturing time for cells in PL1-medium was 125 days until growth arrested, whereas cultures in PL2 and FBS took 121 and 185 days, respectively (Fig. 4).

MSC characterization

The morphology of the cells was typical for MSCs with slight size difference between PL1- and PL2medium cultured cells with PL1 cells appearing smaller (Fig. 5a, b).

All BM-MSC batches tested displayed typical MSC differentiation capacity along the adipogenic, osteogenic and chondrogenic lineages at passage two (Fig. 5c-f). Von Kossa staining of osteogenic cultures revealed a more intense calcium deposition in PL1 containing differentiation medium compared to those differentiated in FBS containing differentiation medium (Fig. 5c, d).

The immunophenotype of the cells from all culture conditions was typical for MSC (Dominici et al. 2006) with the exception of the expression of HLA-DR (Fig. 6). The cells were negative for hematopoietic markers and they expressed typical MSC markers on their surface [CD13, CD29, CD44, CD49e, CD73, CD90, CD105 and HLA-ABC (Table 3)]. The BMMSCs cultured in PL1 supplemented culture media were consistently HLA-DR positive (7.5-66.1\%, Table 3). FBS cultured BM-MSCs were HLA-DR
Fig. 2 Extrapolated MSC yield of $11 \mathrm{BM}-\mathrm{MSC}$ batches cultured in PL1medium at normal atmospheric oxygen conditions. The mean PDs and culture time are shown under each passage and the cumulative mean PD number and the mean value of total culture time are shown on the right-hand side of the table. The range is shown in parenthesis

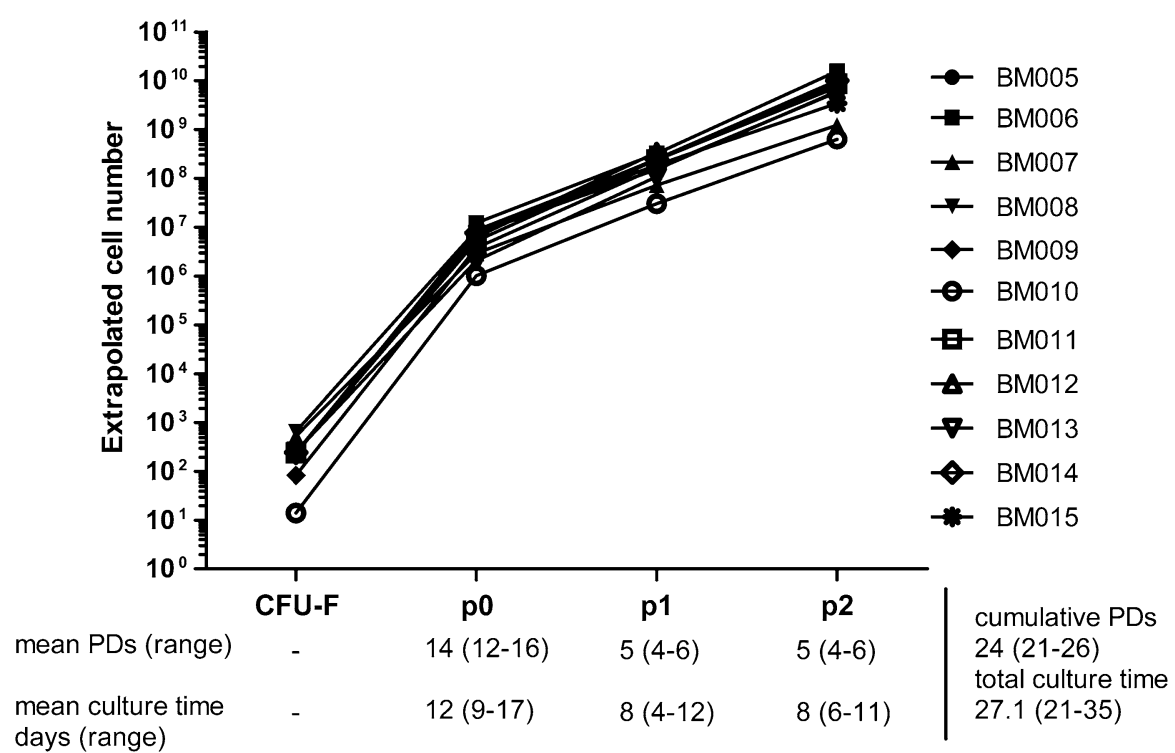




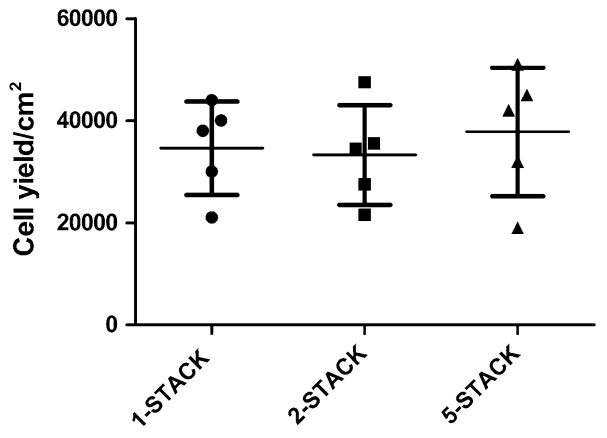

Fig. 3 Cell yields of PL1-cultured BM-MSCs in large-scale vessels (1-, 2- and 5-STACK) in passage 2. Cells were seeded $1,000 \mathrm{cells} / \mathrm{cm}^{2}$ and cultured for one passage. Data show the cell yield $/ \mathrm{cm}^{2} \pm \operatorname{SD}(p=0.79, \mathrm{n}=5)$

negative (Fig. 6). The xenoantigen Neu5Gc was detected on the cell surface of cells cultured in the presence of FBS but not on cells cultured in PL1- and PL2-medium (Fig. 6).

Differently cultured MSCs have similar capacity to suppress $\mathrm{T}$-cell proliferation

The capacity of MSCs to suppress T-cell proliferation was tested in co-culture with PB-MNCs that were stimulated with an anti-CD3 antibody. The MSCs cultured in different conditions were all able to suppress T-cell proliferation at a 1:10-1:50 suppressor:effector ratio. Dose dependence of the suppression was demonstrated with MSCs cultured with PL1 (Fig. 7).

\section{Discussion}

Various animal serum-free culture methods utilizing platelet extracts to support MSC expansion have been published (Bernardo et al. 2007; Bieback et al. 2009;

Fig. 4 Growth kinetics of MSCs in long term culture until growth arrest. Cells were cultured $\mathbf{a}$ in PL1$(n=3)$, b in PL2- and in FBS- (same donors for both, $\mathrm{n}=16$ ) supplemented media from primary cultures to senescence. Data show mean values $\pm \mathrm{SD}$
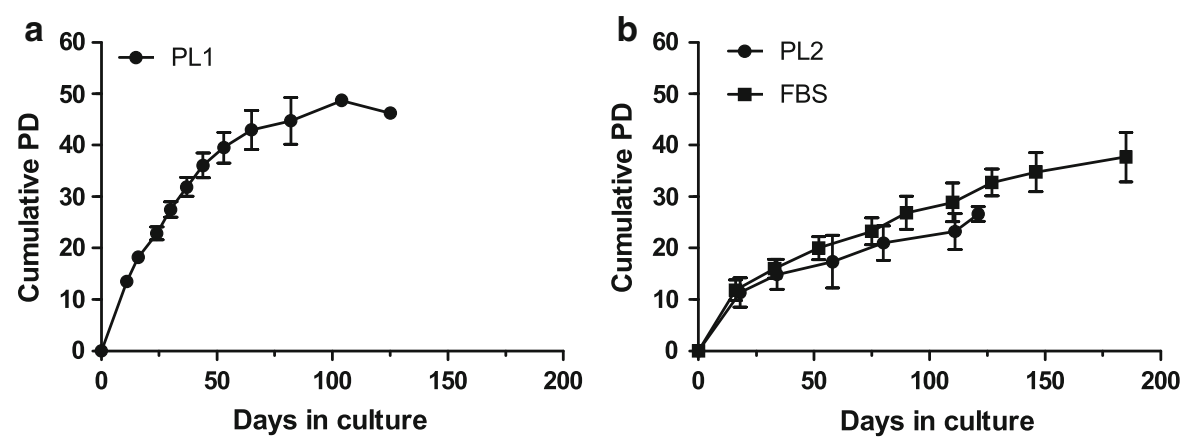


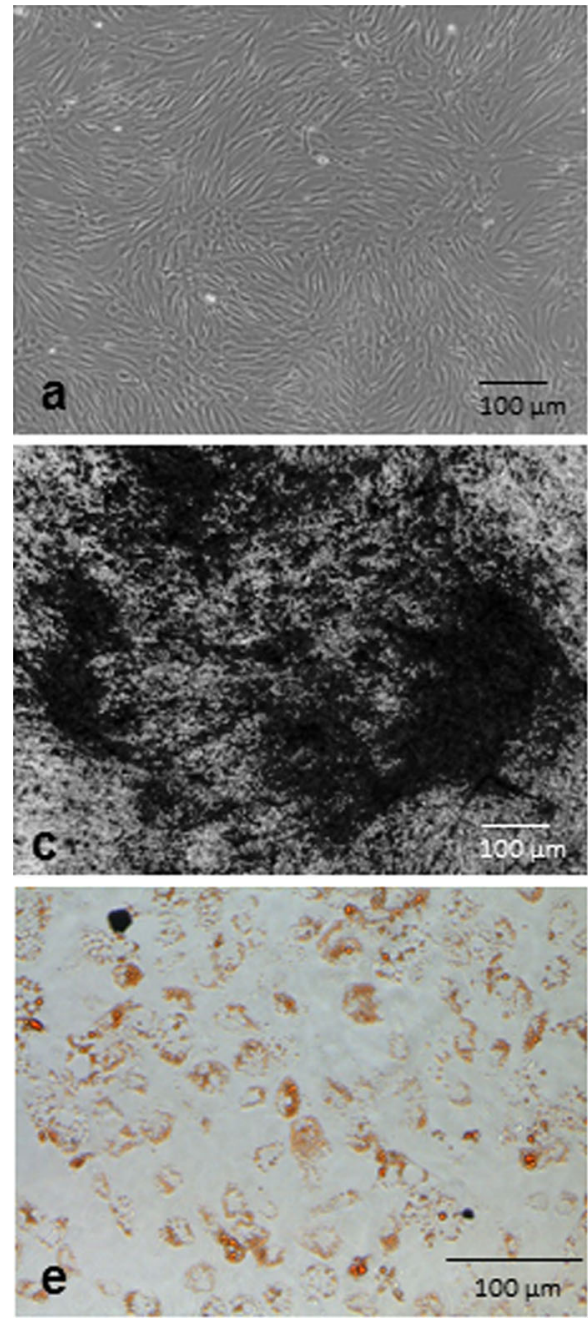

Fig. 5 Representative photographs of cell morphology and differentiation. Morphology of passage 2 cells was normal spindle shaped for both a PL1- and b PL2-medium cultured BMMSCs, but the PL2-cultured cells appeared to have a slightly larger morphology. Von Kossa staining of osteogenic

FBS supplemented medium, which is in agreement with Bernardo et al. (2007).

The main differences between the two PL supplements tested were (1) the higher plasma concentration in PL1 and that (2) PL2 was subjected to several freeze-thaw cycles ( 5 vs 2 , Table 1 ). Our results imply that a higher plasma concentration in the MSC culture media might be beneficial. The importance of the plasma fraction for the initial outgrowth of MSC colonies has also been demonstrated by Horn et al. Horn et al. (2010) who showed that PL alone could not support CFU-F formation. We could, however, not see
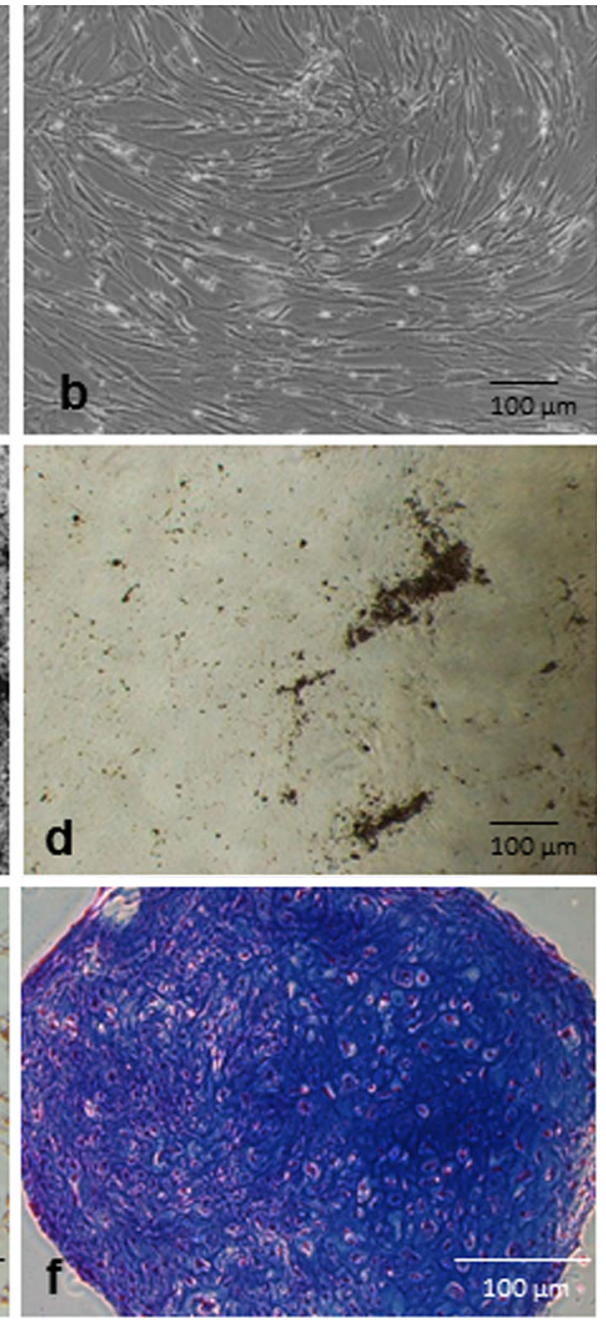

differentiated BM-MSCs in c PL1-supplemented differentiation medium and in d FBS-supplemented differentiation medium. e Sudan III staining indicated the adipogenic differentiation potential of the samples and $\mathbf{f}$ Alcian blue staining indicated the chondrogenic potential of the cells grown in PL1-medium

any benefits of a high number (5) of freeze-thaw cycles. Repeated freezing and thawing might actually negatively affect the growth factor content of plateletderived supplements (Mojica-Henshaw et al. 2013), and the high amount of freeze-thaw cycles during the manufacture of PL2 may have inactivated some critical components of the supplement used in our study. Although the cell yields did not significantly differ between the PL1 and PL2 supplemented protocols, PL1 was superior in that PD time was shorter $(p=0.015)$. It is also worth considering that residues from the virus-inactivated pooled plasma in the PL2- 
FBS
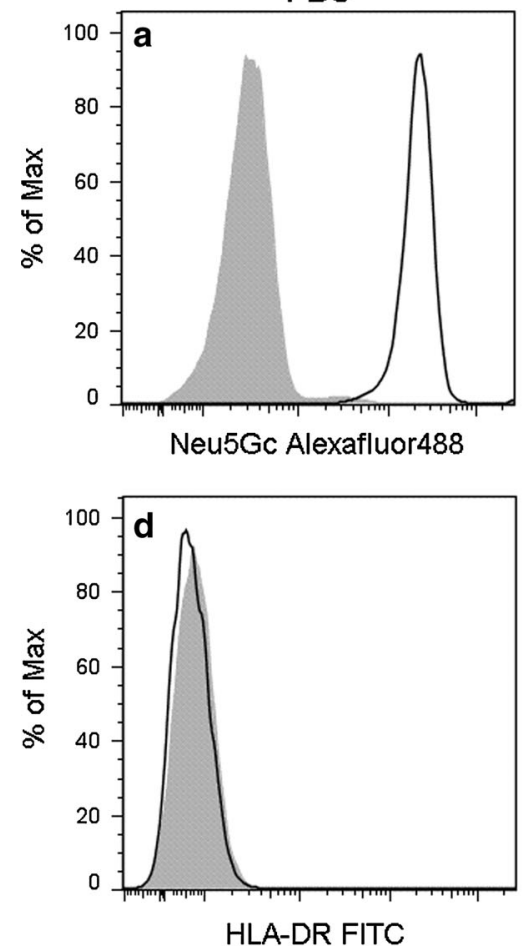

PL1
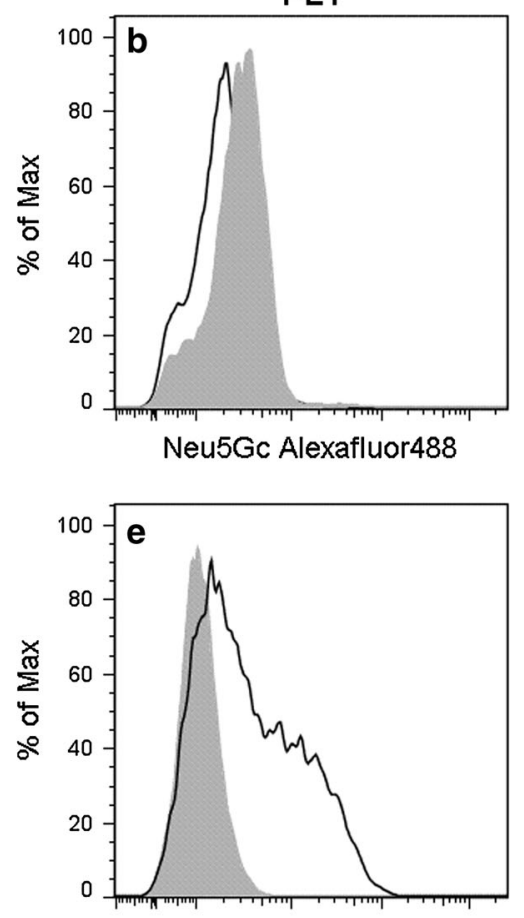

HLA-DR FITC
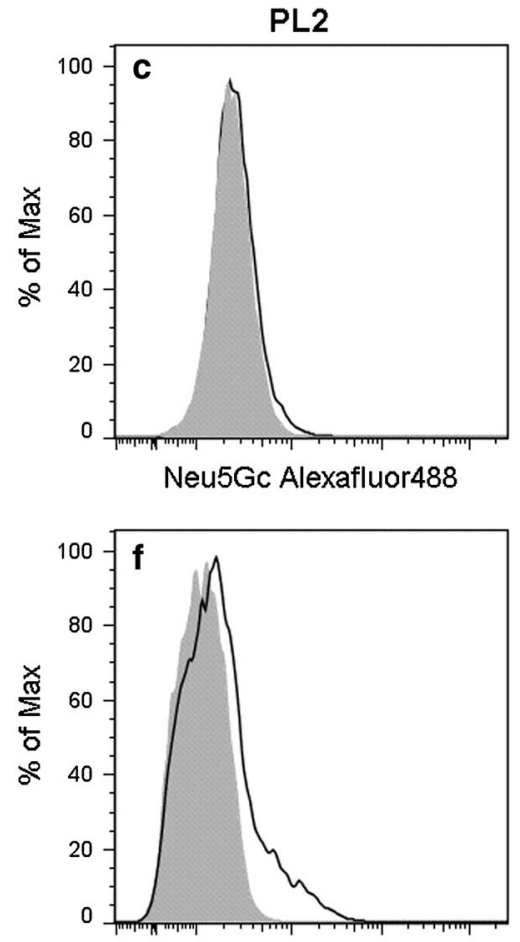

HLA-DR FITC
Fig. 6 Xenoantigenic Neu5Gc contamination and expression of HLA-DR on MSCs. BM-MSCs cultured in a FBS-containing medium stained positively with anti-Neu5Gc whereas cells cultured in b PL1- and in c PL2-media did not have Neu5Gc on their surface. HLA-DR was not expressed on BM-MSCs cultured in d FBS-containing medium but was found on cells cultured in e PL1- and f PL2-medium. Filled histograms represent the unspecific/isotype controls and the solid line the specific staining

pools are produced with high quality standards and according to strict GMP.

Divergent results have been published about the influence of different culture supplements on the number of CFU-Fs in the primary cultures. Some studies have shown that the different culture supplements do not influence the number of proliferating multipotent stem cells, but rather their expansion efficiency. (Ben Azouna et al. 2012; Doucet et al. 2005; Horn et al. 2010; Schallmoser et al. 2007). Our results are in accordance with these data. Some have reported that PL containing media might also increase the number of CFU-Fs (Lange et al. 2007; Salvade et al. 2010). There are also conflicting results regarding the effect of oxygen concentration on the CFU-F number (Fehrer et al. 2007; Lennon et al. 2001). Oxygen concentration is often an ignored component of the culture conditions and cells are kept in normal atmospheric oxygen, the only controlled gas being $\mathrm{CO}_{2}$. The atmospheric $20 \%$ oxygen concentration is 
Table 3 Immunophenotype of BM-MSCs cultured in PL1medium

\begin{tabular}{llclr}
\hline Surface antigen & Mean $\%$ & Max $\%$ & Min $\%$ & $\mathrm{n}$ \\
\hline CD44 & 98.9 & 100.0 & 95.6 & 11 \\
CD49e & 99.0 & 100.0 & 95.5 & 11 \\
CD13 & 99.0 & 100.0 & 95.6 & 11 \\
CD90 & 99.9 & 100.0 & 99.3 & 11 \\
CD73 & 99.9 & 100.0 & 99.2 & 11 \\
CD29 & 99.7 & 100.0 & 98.5 & 11 \\
CD105 & 99.0 & 100.0 & 96.5 & 11 \\
HLA-ABC & 99.6 & 100.0 & 98.6 & 11 \\
CD14 & $<1$ & $<1$ & $<1$ & 5 \\
CD19 & $<1$ & $<1$ & $<1$ & 5 \\
CD34 & $<1$ & 1.8 & $<1$ & 5 \\
CD45 & $<1$ & $<1$ & $<1$ & 5 \\
HLA-DR & 26.8 & 66.1 & 7.5 & 11 \\
\hline
\end{tabular}

Mean percentage and maximum and minimum values of positive cells for each antigen are shown

considerably higher than the 2-9\% oxygen concentration in the natural niche of MSCs (Haque et al. 2013; Mohyeldin et al. 2010). It has been shown in some reports that low oxygen shortens the expansion time of MSCs (Carrancio et al. 2008; Estrada et al.
2012; Grayson et al. 2007) and it has been claimed that the MSC yield could be maximized in low oxygen and the culture time reduced when expanding MSCs at clinical scale (Dos Santos et al. 2010). In these studies the beneficial effect of low oxygen is shown with cells that are from passage 2 or more. Albeit we saw a trend of shorter PD time at $\mathrm{p} 2$ at $3 \%$ oxygen, the effect of low oxygen on BM-MSC proliferation was not significant. Others have also found that oxygen concentration does not influence the proliferation of low passage cells (Fehrer et al. 2007; Karlsen et al. 2011), but PD time is clearly shortened at later passages (Tsai et al. 2011). Low oxygen may have other benefits however, as it may reduce oxidative stress and genetic instability (Chen et al. 1995; Estrada et al. 2012). However, the practicality and economic concerns of the culture protocol are decisive factors in large scale MSC manufacturing. The possible advantage of culturing the cells in low oxygen concentration may be neutralized by its added work and cost. Our results suggest that as long as the cells are expanded only for a few passages the harmful effects of $20 \%$ oxygen are minimal.

The PL1-supplemented culture protocol at $20 \%$ oxygen concentration was chosen for further process development work and was developed towards a clinically and GMP-compliant method. We found that
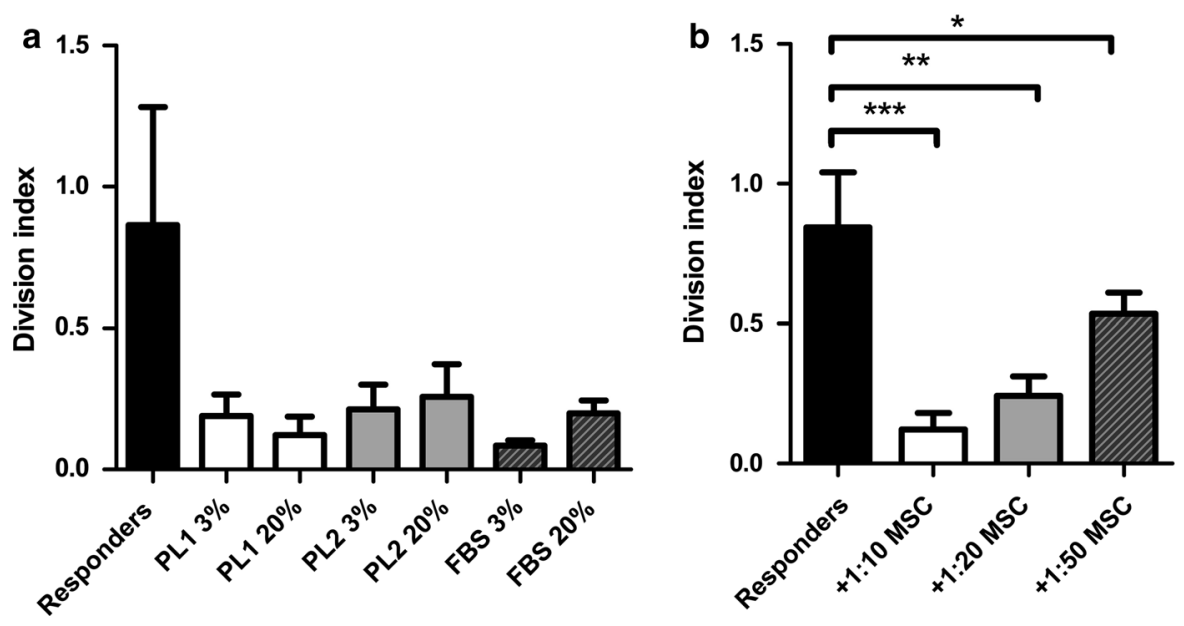

Fig. 7 Immunosuppressive capacity of BM-MSCs cultured in different culture conditions and the dose dependent capacity of the cells to suppress T-cell proliferation. a The results of immunosuppressive capacity of the cells cultured in six different culture conditions at a ratio of MSC:MNC 1:10. Differences between cells from different culturing conditions were statistically non-significant ( 0.14 by one-way ANOVA). b The suppressive capacity of MSCs cultured in PL1-medium was dose dependent. Division index of three independent experiments (mean $+\mathrm{SD})$ is shown indicating the average number of cell divisions. Statistical significance is tested using one-way ANOVA and Tukey's post hoc test $* p<0.05$, $* * p<0.01, * * * p<0.001$ 
MSCs can be cultured with this protocol at large scale using CellStacks ${ }^{\circledR}$ and the method consistently yields MSCs of uniform quality. The cells also essentially fulfilled the MSC minimal criteria set by Mesenchymal and Tissue Stem Cell Committee of International Society of Cell Therapy (ISCT) (Dominici et al. 2006) with one exception, the HLA-DR expression. The cell surface expression of the class II HLA molecule HLADR was consistently positive after culturing in PL, but was absent in cells cultured in FBS (Fig. 6). An induction of HLA-DR expression has been previously reported on MSCs cultured in FBS after cytokine stimulation (Bocelli-Tyndall et al. 2010; Le Blanc et al. 2007; Romieu-Mourez et al. 2007; Turnovcova et al. 2009), and some recent reports have suggested a low expression of HLA-DR on MSCs cultured in PL (Fekete et al. 2012b; Tarte et al. 2010). The expression of HLA-DR has, however, been omitted from numerous papers describing MSC culture in PL (e.g. Doucet et al. 2005; Horn et al. 2010) and we speculate that the HLA-DR expression data have been omitted since it does not fulfill the ISCT minimal criteria for MSCs. The ISCT criteria are formulated using cells cultured in presence of FBS and may not reflect MSCs cultured in differently supplemented media. We found, as also reported by others, that MSCs expressing HLA-DR molecules also possess immunosuppressive capacity, possibly because they lack expression of co-stimulatory molecules (CD80 and CD86) and thus do not elicit an immune reaction (Le Blanc et al. 2007; Menard et al. 2013; Sotiropoulou et al. 2006; Tarte et al. 2010; Tse et al. 2003). Tarte et al. (2010) reported that MSCs that express HLA-DR are poorly immunogenic and efficiently suppress T-cell proliferation in mixed lymphocyte reaction (MLR) and the expression of HLA-DR should not be considered a critical release criterion for MSCs. Duijvestein et al. (2011) hypothesized that pre-activation of MSCs with INF- $\gamma$ that also induces the expression of HLA-DR could lead to more rapid clinical response and hence a lower dose of cells is needed. MSCs may thus receive beneficial activation signals from PL. The functional consequences of the cell surface expression of HLADR is still unknown and would need further investigations, but the ISCT minimal criteria for MSCs might benefit from a re-evaluation for this particular detail.

Neu5Gc is an immunogenic xeno-carbohydrate that is not produced by humans due to the loss of hydroxylase activity of the human CMAH protein
(Irie et al. 1998). MSCs cultured in presence of animal-derived material express this carbohydrate on their surface and intracellular proteins and it mediates immune responses against the cells (Heiskanen et al. 2007; Komoda et al. 2010). We demonstrate that PL1 and PL2 cultured cells are free of this animal-derived contaminant and thus not susceptible to antibodies against Neu5GC which are found in high titers in human serum.

The differentiation assays showed that MSCs cultured in PL1-medium are capable of tri-lineage differentiation. Although the tri-lineage differentiation is used as a criterion for MSCs in the research setting, it may not be relevant if the cells are utilized for immunosuppressive therapy in the clinic. The functional quality control tests for clinical products should be selected with a view to their intended use. In our study we tested the cells' capacity to suppress T-cell proliferation and found effective suppression irrespective of culture condition.

The safety of the MSCs used for clinical purposes should be carefully assessed before administrating the cells to patients. Karyotype testing or other tests measuring genetic stability are often used. However, these tests may not be adequate to find small but deleterious abnormalities (Tarte et al. 2010). In our studies the karyotype was analysed using G-band staining and all tested batches had normal karyotype. Karyotype abnormalities have been noticed by others but usually at late passages and the cells enter into senescence without transformation irrespective of chromosomal alterations (Roselli et al. 2013; Tarte et al. 2010). The risk of tumor formation by MSCs harvested before senescence is, however, considered low (Capelli et al. 2011; Prockop et al. 2010; Tsai et al. 2011) and our protocol is based on a low amount of passaging when the cells are in a proliferative stage. Safety is further increased in our culture protocol by the omission of culture media antibiotics, and an unnecessary patient exposure to beta-lactam and aminoglycoside antibiotics can be avoided. Furthermore, in the absence of antibiotics, the risk of undetected bacterial contamination is reduced.

\section{Conclusions}

We present a robust and reproducible clinicallycompliant culture method for BM-MSCs based on 
PL, which enables high quantities of HLA-DR positive MSCs at a low passage number (p2) and with uniform quality. The cells were consistently HLA-DR positive when cultured in PL, but fulfill all other MSC criteria and suppress T-cell proliferation. The functional consequences of MSC HLA-DR expression need to be clarified in further studies. The animal serum-free, antibiotic-free, large-scale culture protocol can be directly transferred to a cleanroom environment for clinical-grade MSC manufacturing intended for allogeneic clinical use.

Acknowledgments We acknowledge the professional assistance of Sirkka Hirschovits-Gerz and Juha Eronen. This study was supported by Väre Foundation for Pediatric Cancer Research, Finnish Foundation for Pediatric Research, Päivikki and Sakari Sohlberg Foundation and EVO Medical Research Fund of Finnish Red Cross Blood Service.

Open Access This article is distributed under the terms of the Creative Commons Attribution License which permits any use, distribution, and reproduction in any medium, provided the original author(s) and the source are credited.

\section{References}

Aggarwal S, Pittenger MF (2005) Human mesenchymal stem cells modulate allogeneic immune cell responses. Blood 105:1815-1822

Ball LM, Bernardo ME, Roelofs H, van Tol MJ, Contoli B, Zwaginga JJ, Avanzini MA, Conforti A, Bertaina A, Giorgiani G, Jol-van der Zijde CM, Zecca M, Le Blanc K, Frassoni F, Egeler RM, Fibbe WE, Lankester AC, Locatelli F (2013) Multiple infusions of mesenchymal stromal cells induce sustained remission in children with steroid-refractory, grade III-IV acute graft-versus-host disease. Br J Haematol 163:501-509

Ben Azouna N, Jenhani F, Regaya Z, Berraeis L, Ben Othman T, Ducrocq E, Domenech J (2012) Phenotypical and functional characteristics of mesenchymal stem cells from bone marrow: comparison of culture using different media supplemented with human platelet lysate or fetal bovine serum. Stem Cell Res Ther 3:6

Bernardo ME, Avanzini MA, Perotti C, Cometa AM, Moretta A, Lenta E, Del Fante C, Novara F, de Silvestri A, Amendola G, Zuffardi O, Maccario R, Locatelli F (2007) Optimization of in vitro expansion of human multipotent mesenchymal stromal cells for cell-therapy approaches: further insights in the search for a fetal calf serum substitute. J Cell Physiol 211:121-130

Bieback K (2013) Platelet lysate as replacement for fetal bovine serum in mesenchymal stromal cell cultures. Transfus Med Hemother 40:326-335

Bieback K, Hecker A, Kocaomer A, Lannert H, Schallmoser K, Strunk D, Kluter H (2009) Human alternatives to fetal bovine serum for the expansion of mesenchymal stromal cells from bone marrow. Stem Cells 27:2331-2341

Bocelli-Tyndall C, Zajac P, Di Maggio N, Trella E, Benvenuto F, Iezzi G, Scherberich A, Barbero A, Schaeren S, Pistoia V, Spagnoli G, Vukcevic M, Martin I, Tyndall A (2010) Fibroblast growth factor 2 and platelet-derived growth factor, but not platelet lysate, induce proliferation-dependent, functional class II major histocompatibility complex antigen in human mesenchymal stem cells. Arthritis Rheum 62:3815-3825

Capelli C, Domenghini M, Borleri G, Bellavita P, Poma R, Carobbio A, Mico C, Rambaldi A, Golay J, Introna M (2007) Human platelet lysate allows expansion and clinical grade production of mesenchymal stromal cells from small samples of bone marrow aspirates or marrow filter washouts. Bone Marrow Transplant 40:785-791

Capelli C, Gotti E, Morigi M, Rota C, Weng L, Dazzi F, Spinelli O, Cazzaniga G, Trezzi R, Gianatti A, Rambaldi A, Golay J, Introna M (2011) Minimally manipulated whole human umbilical cord is a rich source of clinical-grade human mesenchymal stromal cells expanded in human platelet lysate. Cytotherapy 13:786-801

Carrancio S, Lopez-Holgado N, Sanchez-Guijo FM, Villaron E, Barbado V, Tabera S, Diez-Campelo M, Blanco J, San Miguel JF, Del Canizo MC (2008) Optimization of mesenchymal stem cell expansion procedures by cell separation and culture conditions modification. Exp Hematol 36:1014-1021

Cervenakova L, Akimov S, Vasilyeva I, Yakovleva O, McKenzie C, Cervenak J, Piccardo P, Asher DM (2011) Fukuoka-1 strain of transmissible spongiform encephalopathy agent infects murine bone marrow-derived cells with features of mesenchymal stem cells. Transfusion 51:1755-1768

Chen Q, Fischer A, Reagan JD, Yan LJ, Ames BN (1995) Oxidative DNA damage and senescence of human diploid fibroblast cells. Proc Natl Acad Sci USA 92:4337-4341

Csete M (2005) Oxygen in the cultivation of stem cells. Ann N Y Acad Sci 1049:1-8

Dimarino AM, Caplan AI, Bonfield TL (2013) Mesenchymal stem cells in tissue repair. Front Immunol 4:201

Dominici M, Le Blanc K, Mueller I, Slaper-Cortenbach I, Marini F, Krause D, Deans R, Keating A, Prockop D, Horwitz E (2006) Minimal criteria for defining multipotent mesenchymal stromal cells. The International Society for Cellular Therapy position statement. Cytotherapy 8:315-317

Dos Santos F, Andrade PZ, Boura JS, Abecasis MM, da Silva CL, Cabral JM (2010) Ex vivo expansion of human mesenchymal stem cells: a more effective cell proliferation kinetics and metabolism under hypoxia. J Cell Physiol 223:27-35

Doucet C, Ernou I, Zhang Y, Llense JR, Begot L, Holy X, Lataillade JJ (2005) Platelet lysates promote mesenchymal stem cell expansion: a safety substitute for animal serum in cell-based therapy applications. J Cell Physiol 205:228236

Drela K, Sarnowska A, Siedlecka P, Szablowska-Gadomska I, Wielgos M, Jurga M, Lukomska B, Domanska-Janik K (2014) Low oxygen atmosphere facilitates proliferation and maintains undifferentiated state of umbilical cord 
mesenchymal stem cells in an hypoxia inducible factordependent manner. Cytotherapy 16:881-892

Duijvestein M, Wildenberg ME, Welling MM, Hennink S, Molendijk I, van Zuylen VL, Bosse T, Vos AC, de JongeMuller ES, Roelofs H, van der Weerd L, Verspaget HW, Fibbe WE, te Velde AA, van den Brink GR, Hommes DW (2011) Pretreatment with interferon-gamma enhances the therapeutic activity of mesenchymal stromal cells in animal models of colitis. Stem Cells 29:1549-1558

Estrada JC, Albo C, Benguria A, Dopazo A, Lopez-Romero P, Carrera-Quintanar L, Roche E, Clemente EP, Enriquez JA, Bernad A, Samper E (2012) Culture of human mesenchymal stem cells at low oxygen tension improves growth and genetic stability by activating glycolysis. Cell Death Differ 19:743-755

Fehrer C, Brunauer R, Laschober G, Unterluggauer H, Reitinger S, Kloss F, Gully C, Gassner R, Lepperdinger G (2007) Reduced oxygen tension attenuates differentiation capacity of human mesenchymal stem cells and prolongs their lifespan. Aging Cell 6:745-757

Fekete N, Gadelorge M, Furst D, Maurer C, Dausend J, FleuryCappellesso S, Mailander V, Lotfi R, Ignatius A, Sensebe L, Bourin P, Schrezenmeier H, Rojewski MT (2012a) Platelet lysate from whole blood-derived pooled platelet concentrates and apheresis-derived platelet concentrates for the isolation and expansion of human bone marrow mesenchymal stromal cells: production process, content and identification of active components. Cytotherapy 14:540-554

Fekete N, Rojewski MT, Furst D, Kreja L, Ignatius A, Dausend J, Schrezenmeier H (2012b) GMP-compliant isolation and large-scale expansion of bone marrow-derived MSC. PLoS One $7:$ e43255

Grayson WL, Zhao F, Bunnell B, Ma T (2007) Hypoxia enhances proliferation and tissue formation of human mesenchymal stem cells. Biochem Biophys Res Commun 358:948-953

Griffiths S, Baraniak PR, Copland IB, Nerem RM, McDevitt TC (2013) Human platelet lysate stimulates high-passage and senescent human multipotent mesenchymal stromal cell growth and rejuvenation in vitro. Cytotherapy 15:1469-1483

Haque N, Rahman MT, Abu Kasim NH, Alabsi AM (2013) Hypoxic culture conditions as a solution for mesenchymal stem cell based regenerative therapy. Sci World J 2013:632972

Heiskanen A, Satomaa T, Tiitinen S, Laitinen A, Mannelin S, Impola U, Mikkola M, Olsson C, Miller-Podraza $\mathrm{H}$, Blomqvist M, Olonen A, Salo H, Lehenkari P, Tuuri T, Otonkoski T, Natunen J, Saarinen J, Laine J (2007) $\mathrm{N}$ Glycolylneuraminic acid xenoantigen contamination of human embryonic and mesenchymal stem cells is substantially reversible. Stem Cells 25:197-202

Horn P, Bokermann G, Cholewa D, Bork S, Walenda T, Koch C, Drescher W, Hutschenreuther G, Zenke M, Ho AD, Wagner W (2010) Impact of individual platelet lysates on isolation and growth of human mesenchymal stromal cells. Cytotherapy 12:888-898

Horwitz EM, Gordon PL, Koo WK, Marx JC, Neel MD, McNall RY, Muul L, Hofmann T (2002) Isolated allogeneic bone marrow-derived mesenchymal cells engraft and stimulate growth in children with osteogenesis imperfecta: implications for cell therapy of bone. Proc Natl Acad Sci USA 99:8932-8937

Irie A, Koyama S, Kozutsumi Y, Kawasaki T, Suzuki A (1998) The molecular basis for the absence of $N$-glycolylneuraminic acid in humans. J Biol Chem 273:15866-15871

Karlsen TA, Mirtaheri P, Shahdadfar A, Floisand Y, Brinchmann JE (2011) Effect of three-dimensional culture and incubator gas concentration on phenotype and differentiation capability of human mesenchymal stem cells. J Cell Biochem 112:684-693

Kim EJ, Kim N, Cho SG (2013) The potential use of mesenchymal stem cells in hematopoietic stem cell transplantation. Exp Mol Med 45:e2

Komoda H, Okura H, Lee CM, Sougawa N, Iwayama T, Hashikawa T, Saga A, Yamamoto-Kakuta A, Ichinose A, Murakami S, Sawa Y, Matsuyama A (2010) Reduction of $\mathrm{N}$-glycolylneuraminic acid xenoantigen on human adipose tissue-derived stromal cells/mesenchymal stem cells leads to safer and more useful cell sources for various stem cell therapies. Tissue Eng A 16:1143-1155

Lange C, Cakiroglu F, Spiess AN, Cappallo-Obermann H, Dierlamm J, Zander AR (2007) Accelerated and safe expansion of human mesenchymal stromal cells in animal serum-free medium for transplantation and regenerative medicine. J Cell Physiol 213:18-26

Le Blanc K, Samuelsson H, Lonnies L, Sundin M, Ringden O (2007) Generation of immunosuppressive mesenchymal stem cells in allogeneic human serum. Transplantation 84:1055-1059

Le Blanc K, Frassoni F, Ball L, Locatelli F, Roelofs H, Lewis I, Lanino E, Sundberg B, Bernardo ME, Remberger M, Dini G, Egeler RM, Bacigalupo A, Fibbe W, Ringden O, Developmental Committee of the European Group for Blood and Marrow Transplantation (2008) Mesenchymal stem cells for treatment of steroid-resistant, severe, acute graft-versus-host disease: a phase II study. Lancet 371:1579-1586

Lennon DP, Edmison JM, Caplan AI (2001) Cultivation of rat marrow-derived mesenchymal stem cells in reduced oxygen tension: effects on in vitro and in vivo osteochondrogenesis. J Cell Physiol 187:345-355

Liu L, Xia H, Belak S, Baule C (2008) A TaqMan real-time RTPCR assay for selective detection of atypical bovine pestiviruses in clinical samples and biological products. J Virol Methods 154:82-85

Menard C, Pacelli L, Bassi G, Dulong J, Bifari F, Bezier I, Zanoncello J, Ricciardi M, Latour M, Bourin P, Schrezenmeier H, Sensebe L, Tarte K, Krampera M (2013) Clinical-grade mesenchymal stromal cells produced under various good manufacturing practice processes differ in their immunomodulatory properties: standardization of immune quality controls. Stem Cells Dev 22:1789-1801

Mohyeldin A, Garzon-Muvdi T, Quinones-Hinojosa A (2010) Oxygen in stem cell biology: a critical component of the stem cell niche. Cell Stem Cell 7:150-161

Mojica-Henshaw MP, Jacobson P, Morris J, Kelley L, Pierce J, Boyer M, Reems JA (2013) Serum-converted platelet lysate can substitute for fetal bovine serum in human mesenchymal stromal cell cultures. Cytotherapy 15:1458-1468

Muller I, Kordowich S, Holzwarth C, Spano C, Isensee G, Staiber A, Viebahn S, Gieseke F, Langer H, Gawaz MP, Horwitz EM, Conte P, Handgretinger R, Dominici M 
(2006) Animal serum-free culture conditions for isolation and expansion of multipotent mesenchymal stromal cells from human BM. Cytotherapy 8:437-444

Pittenger MF, Mackay AM, Beck SC, Jaiswal RK, Douglas R, Mosca JD, Moorman MA, Simonetti DW, Craig S, Marshak DR (1999) Multilineage potential of adult human mesenchymal stem cells. Science 284:143-147

Prasad VK, Lucas KG, Kleiner GI, Talano JA, Jacobsohn D, Broadwater G, Monroy R, Kurtzberg J (2011) Efficacy and safety of ex vivo cultured adult human mesenchymal stem cells (Prochymal) in pediatric patients with severe refractory acute graft-versus-host disease in a compassionate use study. Biol Blood Marrow Transplant 17:534-541

Prockop DJ, Brenner M, Fibbe WE, Horwitz E, Le Blanc K, Phinney DG, Simmons PJ, Sensebe L, Keating A (2010) Defining the risks of mesenchymal stromal cell therapy. Cytotherapy 12:576-578

Ren H, Cao Y, Zhao Q, Li J, Zhou C, Liao L, Jia M, Zhao Q, Cai H, Han ZC, Yang R, Chen G, Zhao RC (2006) Proliferation and differentiation of bone marrow stromal cells under hypoxic conditions. Biochem Biophys Res Commun 347:12-21

Ringden O, Uzunel M, Rasmusson I, Remberger M, Sundberg B, Lonnies H, Marschall HU, Dlugosz A, Szakos A, Hassan Z, Omazic B, Aschan J, Barkholt L, Le Blanc K (2006) Mesenchymal stem cells for treatment of therapy-resistant graft-versus-host disease. Transplantation 81:1390-1397

Romieu-Mourez R, Francois M, Boivin MN, Stagg J, Galipeau J (2007) Regulation of MHC class II expression and antigen processing in murine and human mesenchymal stromal cells by IFN-gamma, TGF-beta, and cell density. J Immunol 179:1549-1558

Roselli EA, Lazzati S, Iseppon F, Manganini M, Marcato L, Gariboldi MB, Maggi F, Grati FR, Simoni G (2013) Fetal mesenchymal stromal cells from cryopreserved human chorionic villi: cytogenetic and molecular analysis of genome stability in long-term cultures. Cytotherapy 15:1340-1351

Salvade A, Della Mina P, Gaddi D, Gatto F, Villa A, Bigoni M, Perseghin P, Serafini M, Zatti G, Biondi A, Biagi E (2010) Characterization of platelet lysate cultured mesenchymal stromal cells and their potential use in tissue-engineered osteogenic devices for the treatment of bone defects. Tissue Eng C Methods 16:201-214

Schallmoser K, Bartmann C, Rohde E, Reinisch A, Kashofer K, Stadelmeyer E, Drexler C, Lanzer G, Linkesch W, Strunk D (2007) Human platelet lysate can replace fetal bovine serum for clinical-scale expansion of functional mesenchymal stromal cells. Transfusion 47:1436-1446

Sensebe L, Bourin P (2009) Mesenchymal stem cells for therapeutic purposes. Transplantation 87:S49-S53

Shafaei H, Esmaeili A, Mardani M, Razavi S, Hashemibeni B, Nasr-Esfahani MH, Shiran MB, Esfandiari E (2011) Effects of human placental serum on proliferation and morphology of human adipose tissue-derived stem cells. Bone Marrow Transplant 46:1464-1471
Shahdadfar A, Fronsdal K, Haug T, Reinholt FP, Brinchmann JE (2005) In vitro expansion of human mesenchymal stem cells: choice of serum is a determinant of cell proliferation, differentiation, gene expression, and transcriptome stability. Stem Cells 23:1357-1366

Shetty P, Bharucha K, Tanavde V (2007) Human umbilical cord blood serum can replace fetal bovine serum in the culture of mesenchymal stem cells. Cell Biol Int 31:293-298

Shi M, Liu ZW, Wang FS (2011) Immunomodulatory properties and therapeutic application of mesenchymal stem cells. Clin Exp Immunol 164:1-8

Sotiropoulou PA, Perez SA, Salagianni M, Baxevanis CN, Papamichail M (2006) Characterization of the optimal culture conditions for clinical scale production of human mesenchymal stem cells. Stem Cells 24:462-471

Suila H, Pitkanen V, Hirvonen T, Heiskanen A, Anderson H, Laitinen A, Natunen S, Miller-Podraza H, Satomaa T, Natunen J, Laitinen S, Valmu L (2011) Are globoseries glycosphingolipids SSEA-3 and -4 markers for stem cells derived from human umbilical cord blood? J Mol Cell Biol 3:99-107

Sullivan M, Galea P, Latif S (2006) What is the appropriate oxygen tension for in vitro culture? Mol Hum Reprod 12:653

Sundin M, Ringden O, Sundberg B, Nava S, Gotherstrom C, Le Blanc K (2007) No alloantibodies against mesenchymal stromal cells, but presence of anti-fetal calf serum antibodies, after transplantation in allogeneic hematopoietic stem cell recipients. Haematologica 92:1208-1215

Tarte K, Gaillard J, Lataillade JJ, Fouillard L, Becker M, Mossafa H, Tchirkov A, Rouard H, Henry C, Splingard M, Dulong J, Monnier D, Gourmelon P, Gorin NC, Sensebe L, Societe Francaise de Greffe de Moelle et Therapie Cellulaire (2010) Clinical-grade production of human mesenchymal stromal cells: occurrence of aneuploidy without transformation. Blood 115:1549-1553

Tsai CC, Chen YJ, Yew TL, Chen LL, Wang JY, Chiu CH, Hung SC (2011) Hypoxia inhibits senescence and maintains mesenchymal stem cell properties through down-regulation of E2A-p21 by HIF-TWIST. Blood 117:459-469

Tse WT, Pendleton JD, Beyer WM, Egalka MC, Guinan EC (2003) Suppression of allogeneic T-cell proliferation by human marrow stromal cells: implications in transplantation. Transplantation 75:389-397

Turnovcova K, Ruzickova K, Vanecek V, Sykova E, Jendelova P (2009) Properties and growth of human bone marrow mesenchymal stromal cells cultivated in different media. Cytotherapy 11:874-885

Wasterlain AS, Braun HJ, Dragoo JL (2012) Contents and formulations of platelet-rich plasma. Oper Tech Orthop 22:33-42

Yen BL, Yen ML, Hsu PJ, Liu KJ, Wang CJ, Bai CH, Sytwu HK (2013) Multipotent human mesenchymal stromal cells mediate expansion of myeloid-derived suppressor cells via hepatocyte growth factor/c-Met and STAT3. Stem Cell Reports 1:139-151 